\title{
Socio-Economic Indicators and its Implication on Unemployment: Empirical Study in Six Provinces in Indonesia
}

\author{
Debby Nindya Istiandari, Lilis Siti Badriah, Kamio
}

Faculty of Economics and Business, Jenderal Soedirman University, Central Java, Indonesia

\begin{abstract}
This study was aimed to analyze the influence of the primary sector of GRDP, secondary sector of GRDP, tertiary sector of GRDP, basic education graduates, middle education graduates, higher education graduates, male morbidity rate, female morbidity rate, and population growth on the unemployment rate in six provinces in Indonesia including Special Capital Region of Jakarta, West Java, Central Java, Special Region of Yogyakarta, East Java, and Banten Provinces. The data type of this study was secondary data for the period of 2009-2018 and cross data of the six provinces, whereas the data analysis technique used was panel data regression analysis. From the result, it was found that the basic education graduates and population growth on the significance level of 1 percent have a significant influence, while the secondary sector of GRDP, tertiary sector of GRDP, higher education, and the male morbidity rate were found to have a significant influence on the unemployment rate with the significant rate of 5 percent.
\end{abstract}

Keywords: unemployment, economic sectors, human capital, population

DOI: $10.7176 / \mathrm{JESD} / 11-4-07$

Publication date: February $29^{\text {th }} 2020$

\section{Introduction}

Indonesia is an archipelago state with 34 provinces. Amongst the island and big islands in Indonesia, Java Island comprises of six provinces is an island with the highest population density compared to other islands as can be seen in the following table.

Table 1. Percentage of Indonesian Population Distribution of 2017

\begin{tabular}{lcc}
\hline & Island & Population Distribution \\
\hline Sumatra & 21.75 \\
Java & 56.58 \\
Kalimantan & 6.08 \\
Sulawesi & 7.34 \\
Others & 8.26 \\
\hline
\end{tabular}

Source: Data and Information Center of the Indonesian Ministry of Health

Table 1 shows that Java Island became the most populous island compared to other islands, even more than 50 percent of the Indonesian population resides on this island. Along with the high population, Java Island surely has various problems hard to avoid. From the various problems in Java Island, unemployment is a problem so far being continuously highlighted due to the increasing percentage and it can be said that it is inarguably high as can be seen in the following picture.

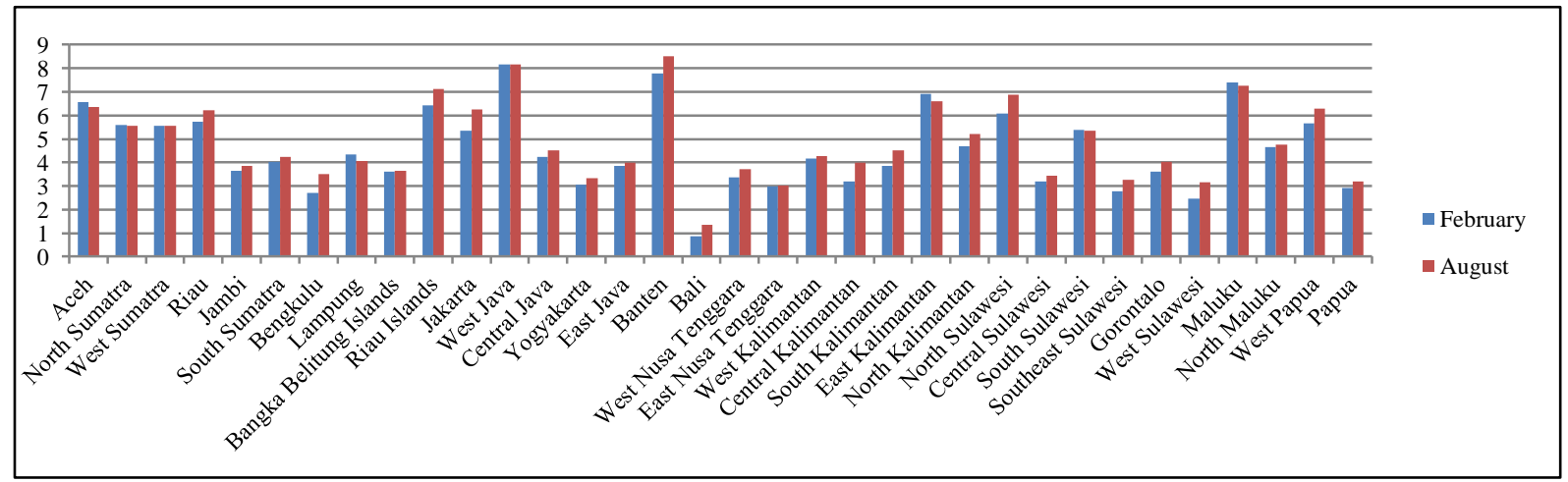

Source: BPS-Statistics Indonesia

Figure 1. Open Unemployment Rate by Province in Indonesia of 2018 
According to Edgar O. Edwards (1974) (in Arsyad, 2015), open unemployment is those who are not working voluntarily (not willing to work because they expect better jobs) or forced not working (willing to work but not getting jobs). Figure 1 shows that the unemployment rate in the provinces of Java Island including Special Capital Region of Jakarta, West Java, Central Java, Special Region of Yogyakarta, East Java, and Banten Provinces in 2018 was increased. The six provinces also have a considerably high unemployment rate, even two provinces in Java Island, namely West Java and Banten became the provinces with the highest unemployment rate in Indonesia.

The high unemployment rate in the provinces of Java Island is inversely proportional to the massive development of economic or social infrastructure, even more, massive compared to other provinces outside Java Island. Empirically, infrastructure availability having a strong connection with the regional development rate in which among others characterized by the high economic growth that should be in line with the construction problems decrease, one of which is unemployment. The high economic growth meaning that the economic activities turn better due to the emergence of new projects, more active trading activities, or the arising or growth of various sectors caused by high demand should be able to employ more workers, and the condition should be effective enough in decreasing the unemployment. This study was trying to analyze how in fact the influence of socio-economic indicators including economic sectors, human capital represented by education and health indicators, as well as population growth toward the unemployment rate in six provinces in Indonesia.

\section{Literature Review}

According to the System of National Accounts published by the United Nation (in Rahayu, 2010), the economy of a region by the business field consists of three main sectors, namely primary, secondary, and tertiary sectors. The connection between the primary sector, secondary sector, and tertiary sector of Gross Regional Domestic Product (GRDP) with unemployment may refer to the Okun law. In this law, it is explained that there is a close relationship with the negative relation between the unemployment rate year to year and the changes in the real GDP from year to year (Mankiw, 2007) in which the unemployment rate will decrease along with the increase of GDP. Then, Arsyad (2015) explained that high economic growth will create a reduction scheme of unemployment, in which the high economic growth is expected to be able to create an output growth so that more workers are required in order to meet the increased output capacity. In relation to the connection between sectoral GRDP and unemployment rate, the study result conducted by Aryeetey and Baah-Boateng (2007) revealed that the agriculture and manufacture sectors became one of the sectors having the highest employment rate although the investment rate in these sectors is deemed low. In addition, Adarkwa et al. (2017) showed that the service sector has a negative relation and a significant influence on unemployment.

Meanwhile, human capital are the most frequently used term in education, health, and other human capacities that can enhance productivity if those are increased. Education according to Langeveld (in Hasbullah, 2008) is described as every effort and influence given to children to help them so that they are capable enough to perform their own life duties. Education's indicators comprising of: (1) basic education graduates, including elementary school and middle school, (2) middle education, including high school and vocation high school, and (3) higher education, including diploma graduates and bachelor either in national or private institution having negative relation with unemployment, that is when the number of graduates is increased the unemployment rate will decrease. This is because if the graduates number of basic education increased, then it is possible that the population number (specifically those of school-age) continuing to higher education will also increase, and the higher the education level completed, the higher the possibility for employment with a higher salary. In line with the study conducted by Riddell and Song (2011), the result showed that education has a significant influence on re-employment.

Whereas in relation to health indicator, to see the morbidity number it shall be differentiated between male and female residences. This is based on the study conducted by Liang et al. (2017) which indicated that there is a striking difference on the gene expression between male and female, in which this difference is not only contributing to the vulnerability to caught disease but also increasing the disease activity, this result also showed that female have higher risk in developing autoimmune disease. In the study conducted by Antonisse and Garfield (2018) it was elaborated that there is strong evidence for the positive relationship between poor health and unemployment, in which poor health increases the risk for losing a job.

Unemployment is inseparable from the population especially the productive population category (aged from 15 to 64 years old). The relation between population growth and unemployment rate lies in the fact that if the population number keeps increasing but jobs and basic facilities are not sufficient then it shall increase unemployment. As explained by Todaro (2000) that population growth encourages economic, social, and psychological problems closely related to the recent condition and also hindering better life prospects. Migration theory from Todaro also explained the existence of characteristics in which the migration exceeding the employment opportunity growth rate in cities is highly possible, so high unemployment in cities is inevitable due to the poor imbalance between economic opportunities in urban and rural (Arsyad, 2015). As in the study conducted by Maqbool et al. (2013), it indicated that the population has a positive relation and 
significant influence on unemployment.

\section{Methods}

The approach used in this study was a quantitative approach using a literature study. The data type used was time series secondary data for the period between 2009 and 2018, and cross data of six provinces including Special Capital Region of Jakarta, West Java, Central Java, Special Region of Yogyakarta, East Java, and Banten Provinces, where both of these data characteristics were combined and called panel data or pooled data. Independent variables in this study consists of primary sector of GRDP (PRIMARY), secondary sector of GRDP (SECONDARY), tertiary sector of GRDP (TERTIARY), basic education (BASICEDU), middle education (MIDDLEEDU), higher education (HIGHEREDU), male morbidity rate (MORBIDM), female morbidity rate (MORBIDF), and population growth (POP), while the dependent variable was unemployment rate (UNEM).

\section{UNEM $=\mathrm{f}($ PRIMERY, SECONDARY, TERTIARY, BASICEDU, MIDDLEEDU, HIGHEREDU, MORBIDM, MORBIDF, POP)}

For an operational definition from the variables used in this study, it can be seen in the following table.

Table 2. Variable Operationalization

\begin{tabular}{|c|c|c|}
\hline Variable & Concept & Unit \\
\hline $\begin{array}{l}\text { Unemployment } \\
\text { Rate }\end{array}$ & $\begin{array}{l}\text { The percentage of the workforce in Special Capital Region of Jakarta, West Java, Central Java, Special } \\
\text { Region of Yogyakarta, East Java, and Banten Provinces who totally have no jobs. }\end{array}$ & Percent \\
\hline $\begin{array}{l}\text { Primary Sector of } \\
\text { GRDP }\end{array}$ & $\begin{array}{l}\text { The number of goods and services produced by all economic units in Special Capital Region of Jakarta, } \\
\text { West Java, Central Java, Special Region of Yogyakarta, East Java, and Banten Provinces in the primary } \\
\text { sector. }\end{array}$ & Rupiah \\
\hline $\begin{array}{l}\text { Secondary Sector } \\
\text { of GRDP }\end{array}$ & $\begin{array}{l}\text { The number of goods and services produced by all economic units in Special Capital Region of Jakarta, } \\
\text { West Java, Central Java, Special Region of Yogyakarta, East Java, and Banten Provinces in the } \\
\text { secondary sector. }\end{array}$ & Rupiah \\
\hline $\begin{array}{l}\text { Tertiary Sector of } \\
\text { GRDP }\end{array}$ & $\begin{array}{l}\text { The number of goods and services produced by all economic units in Special Capital Region of Jakarta, } \\
\text { West Java, Central Java, Special Region of Yogyakarta, East Java, and Banten Provinces in the tertiary } \\
\text { sector. }\end{array}$ & Rupiah \\
\hline $\begin{array}{l}\text { Basic Education } \\
\text { Graduates }\end{array}$ & $\begin{array}{l}\text { The number of population in Special Capital Region of Jakarta, West Java, Central Java, Special Region } \\
\text { of Yogyakarta, East Java, and Banten Provinces who have completed the formal education of } \\
\text { Elementary School and Middle School. }\end{array}$ & Person \\
\hline $\begin{array}{l}\text { Middle Education } \\
\text { Graduates }\end{array}$ & $\begin{array}{l}\text { The population in Special Capital Region of Jakarta, West Java, Central Java, Special Region of } \\
\text { Yogyakarta, East Java, and Banten Provinces who have completed the formal education of High School } \\
\text { and Vocational High School. }\end{array}$ & Person \\
\hline $\begin{array}{l}\text { Higher Education } \\
\text { Graduates }\end{array}$ & $\begin{array}{l}\text { The number of population in Special Capital Region of Jakarta, West Java, Central Java, Special Region } \\
\text { of Yogyakarta, East Java, and Banten Provinces who have completed the formal education of Diploma } \\
\text { 1, Diploma 2, Diploma 3, Diploma 4, and Bachelor Degree. }\end{array}$ & Person \\
\hline $\begin{array}{l}\text { Male Morbidity } \\
\text { Rate }\end{array}$ & $\begin{array}{l}\text { The percentage of male residences in Special Capital Region of Jakarta, West Java, Central Java, } \\
\text { Special Region of Yogyakarta, East Java, and Banten Provinces suffering health complaints or other } \\
\text { complaints including male residences having an acute or chronic disease. }\end{array}$ & Percent \\
\hline $\begin{array}{l}\text { Female Morbidity } \\
\text { Rate }\end{array}$ & $\begin{array}{l}\text { The percentage of female residences in Special Capital Region of Jakarta, West Java, Central Java, } \\
\text { Special Region of Yogyakarta, East Java, and Banten Provinces suffering health complaints or other } \\
\text { complaints including female residences having an acute or chronic disease. }\end{array}$ & Percent \\
\hline $\begin{array}{l}\text { Population } \\
\text { Growth }\end{array}$ & $\begin{array}{l}\text { The percentage of population number change in Special Capital Region of Jakarta, West Java, Central } \\
\text { Java, Special Region of Yogyakarta, East Java, and Banten Provinces due to birth, mortality, and } \\
\text { migration factors. }\end{array}$ & Percent \\
\hline
\end{tabular}

The data analysis model used in this study was the regression analysis model as follows:

UNEMit $=\beta_{0}+\beta_{1} \log$ PRIMERYit $+\beta_{2} \operatorname{logSECONDARYit}+\beta_{3} \log$ TERTIARYit $+\beta_{4} \operatorname{logBASICEDUit}+\beta_{5}$ $\log$ MIDDLEEDUit $+\beta_{6} \operatorname{logHIGHEREDUit}+\beta_{7}$ MORBIDMit $+\beta_{8}$ MORBIDFit $+\beta_{9}$ POPit + eit 
This study used a panel data regression analysis technique with semi-log regression model. Panel data regression is a regression technique combining time series data and cross-sectional data (Basuki and Prawoto, 2016). Panel data analysis technique can be performed by common effect, fixed effect, or random effect model, while to determine the most suitable model with this study chow, hausman, and multiplier lagrange tests were conducted. After choosing the model, a classic assumption test was conducted including normality, heteroscedasticity, and multicollinearity tests, which then continued by a hypothesis test using $\mathrm{t}$ and $\mathrm{F}$ tests.

\section{Result and Discussion}

This section suggested the result and discussion regarding the effect of the socio-economic indicators of unemployment rate in six provinces precisely in Java Island.

\subsection{Model Determination Test (Goodness of Fit)}

The test result of the proper model might be seen in the below table.

Table 3. Test Result of Model Determination

\begin{tabular}{lccc}
\hline \multicolumn{1}{c}{ Effects Test } & Statistic & d.f. & Prob. \\
\hline Cross-section F & 33.950963 & $(5,45)$ & 0.0000 \\
Cross-section Chi-square & 93.770070 & 5 & 0.0000 \\
\hline
\end{tabular}

Source: Authors Computation from Eviews. Chow Test

Upon the test of model selection, it was discovered that the fixed effect was a proper model to be used within this research. It was due to the fact that upon chow test, it was found that the probability value was 0.0000 , in which this value was less than 0.05 , in other words, fixed-effect model (FEM) was more appropriately used rather than common effect model (CEM). FEM was selected by chow test, therefore Lagrange multiplier test was not conducted, because it would be carried out if CEM was selected. Hausman test generally carried out to determine a more precise model between FEM and random effect model (REM) was not conducted as well, due to the fact that the amount of cross-section was less than the number of coefficients for between estimator for estimate of RE innovation variance.

\subsection{Classical Assumption Test}

Upon the proper model was obtained, then the classical assumption test was carried out including normality, heteroscedasticity, and multicollinearity test.

\subsubsection{Normality Test}

The normality test aimed to discover whether the residual data were distributed normally or not. The test revealed that the probability value of Jarque-bera was 0.678968 , in which this value was higher than 0.05 where its residual was normally distributed.

\subsubsection{Heteroscedasticity Test}

The test result of heteroscedasticity could be seen in Table 4 .

Table 4. The Result of Glejser Test

\begin{tabular}{lllc}
\hline \multicolumn{1}{c}{ Variable } & Prob. & \multicolumn{1}{c}{ Variable } & Prob. \\
\hline LogPRIMERY & 0.0885 & LogHIGHEREDU & 0.7008 \\
LogSECONDARY & 0.0362 & MORBIDM & 0.8830 \\
LogTERTIARY & 0.6298 & MORBIDF & 0.6142 \\
$\operatorname{logBASICEDU~}$ & 0.5017 & POP & 0.0267 \\
$\log$ MIDDLEEDU & 0.5183 & & \\
\hline
\end{tabular}

Source: Authors Computation from Eviews

Heteroscedasticity occurred when a variant of each disturbance element was inconstant. By Glejser test, it was founded that any probability of free variable in which its value was less than 0.05 , meaning that any heteroscedasticity, therefore correction was required to be conducted using White method.

\subsubsection{Multicollinearity Test}

After the correction of heteroscedasticity using White procedure and there were no more problems, then multicollinearity using correlation matrix in which its result showed suggested that any free variable having high correlation coefficient value 
was variable graduating basic education (BASICEDU) with variable obtaining middle education (MIDDLEEDU), as well as the number of morbid men (MORBIDM) with the number of morbid females (MORBIDF).

The result of the correlation matrix revealed that the correlation coefficient between basic education and middle education graduations was in the amount of 0.971015 . The high correlation between these two variables could be resulted in two factors. First, psychological condition and pressure. It could not be denied that along with the current development followed by the openness would make the citizens think to continue their education. It was not merely due to psychological condition and society's pressure, moreover, it was also due to working pressure, in which the performance quality gained by one was based on education. Consequently, it affected the correlation of education which would also be higher due to the high number to continue the education.

Second, compulsory education for 12 years as specified by the government. In Indonesia history education, there were several policy phases regarding compulsory education commencing from 1950 when the government implemented the trial of compulsory education for 6 years, then in 1984, the government declared the Compulsory Education Movement for 6 years (elementary school), in 1994, the government suggested the Compulsory Education Movement for 9 years (junior high school), and in 2015, they declared the Compulsory Education Movement for 12 years (senior high school). 12 years' compulsory education also followed by other policy to encourage in achieving the target such as Smart Indonesia Program was sufficiently effective to boost the number of citizen continuing middle education, it would be more realizable if the variable of basic education and middle education graduation had high correlation, due to the fact that if more people obtained basic education, more people continued their education and obtained the middle education.

Meanwhile, the high correlation between the number of morbid man and morbid female variable resulting the correlation value of 0.968445 could be caused by the high disease transmission among inter-individual within a family or with an individual within their surroundings, as mentioned in the previous section that Java Island is the highest population in Indonesia, also meaning that its population density was completely high, the possibility of disease transmission among the individual was also immense. As stipulated in the data of Health Minister of the Republic of Indonesia suggesting that the most patients of communicable disease were in Java Island, such as leprosy, HIV/AIDS, Hepatitis A, Tuberculosis, Diphtheria, indeed for several cases, they were deemed as extraordinary even.

According to Gujarati (in Ghozali and Ratmono, 2013), there were two choices to be performed if there was any multicollinearity problem: (1) do nothing, and (2) execute the specified rule of thumb. In order to obtain the accurate result of the estimated parameter, paradigm of rule of thums was selected to be used in this research, in which in accordance with this paradigm, there are various ways to treat serious multicollinearity, and one of the most possible way by expelling the independent variable with high correlation. The new model of this research was:

UNEMit $=\beta_{0 \mathrm{i}}+\beta_{1} \log$ PRIMERYit $+\beta_{2} \operatorname{logSECONDARYit}+\beta_{3} \log$ TERTIARYit $+\beta_{4} \operatorname{logBASICEDUit}+\beta_{5}$ $\operatorname{logHIGHEREDUit}+\beta_{6}$ MORBIDMit $+\beta_{7}$ POPit + eit

By releasing the variable graduating middle education (MIDDLEEDU) from model which based on data published by BPS-Statistics Indonesia.

Table 5. Mean Years School Based on Province in Java Island in 2016-2018

\begin{tabular}{lrrr}
\hline \multirow{2}{*}{ Province } & \multicolumn{3}{c}{ Mean Years School } \\
\cline { 2 - 4 } & $\mathbf{2 0 1 6}$ & $\mathbf{2 0 1 7}$ & $\mathbf{2 0 1 8}$ \\
\hline Special Capital Region of Jakarta & 10.88 & 11.02 & 11.05 \\
West Java & 7.95 & 8.14 & 8.15 \\
Central Java & 7.15 & 7.27 & 7.35 \\
Special Region of Yogyakarta & 9.12 & 9.19 & 9.32 \\
East Java & 7.23 & 7.34 & 7.39 \\
Banten & 8.37 & 8.53 & 8.62 \\
\hline
\end{tabular}

Source: BPS-Statistics Indonesia

Table 5 revealed that the mean years school of major resident in Java Island was around 7 to 9 years or equal to grade 1 to grade 3 of junior high school, and there was merely one province i.e. Special Capital Region of Jakarta in which the mean years school of its resident obtained 11 years or equal to grade 2 of senior high school. In fact, the number of those obtaining basic education was seemingly more properly to be used than middle education.

Meanwhile, one of the reasons why the number of morbid female residents (MORBIDF) was expelled was based on the following data. 
Table 6. Population Based on Province in Java Island in 2017

\begin{tabular}{|c|c|c|}
\hline \multirow{2}{*}{ Province } & \multicolumn{2}{|c|}{ Population } \\
\hline & Male & Female \\
\hline Special Capital Region of Jakarta & $5,230,298$ & $5,113,720$ \\
\hline West Java & $24,335,331$ & $23,702,496$ \\
\hline Central Java & $16,988,093$ & $17,269,772$ \\
\hline Special Region of Yogyakarta & $1,860,869$ & $1,901,298$ \\
\hline East Java & $19,397,878$ & $19,895,094$ \\
\hline Banten & $6,344,428$ & $6,103,732$ \\
\hline Total & $74,156,897$ & $74,013,112$ \\
\hline
\end{tabular}

Source: BPS-Statistics of DKI Jakarta Province, BPS-Statistics of Jawa Barat Province, BPS-Statistics of Jawa Tengah Province, BPS-Statistics of DI Yogyakarta Province, BPS-Statistic of Jawa Timur Province, BPS-Statistics of Banten Province

The table above suggested that although, there were three provinces having more female residents, if the whole number of residents in Java Island was calculated, it would reveal the more male resident than female resident with the difference of 143,785 people. Besides its number, female resident basically was not too sensitive toward the unemployment date due to the fact that they gaining productive age, however not working and going to school still could not be specified into unemployment group because they were not included in the labor force (not workforce, like housewife).

\subsection{Regression Result and Hypothesis Test}

Upon the data collection using FEM, it revealed the results as follows.

Table 7. Regression Result

\begin{tabular}{lccc}
\hline \multicolumn{1}{c}{ Regressor } & Coefficient & Standard Error & t-Statistic (Prob.) \\
\hline $\log$ PRIMERY & -0.173947 & 0.172889 & $-1.006118(0.3195)$ \\
$\operatorname{logSECONDARY~}$ & -0.280066 & 0.124556 & $-2.248520(0.0293)$ \\
$\log$ TERTIARY & -0.231207 & 0.100173 & $-2.308085(0.0254)$ \\
$\operatorname{logBASICEDU~}$ & -5.494687 & 2.009698 & $-2.734086(0.0088)$ \\
$\operatorname{logHIGHEREDU~}$ & -1.059588 & 0.426799 & $-2.482637(0.0167)$ \\
MORBIDM & 0.204497 & 0.077239 & $2.647601(0.0110)$ \\
POP & 0.152414 & 0.054480 & $2.797606(0.0074)$ \\
C & 113.7011 & 23.58571 & $4.820763(0.0000)$ \\
\hline F-statistic (Prob.) & $43.83352(0.000000)$ & & \\
R-squared & 0.917976 & & \\
Durbin-Watson stat & 1.611246 & & \\
\hline
\end{tabular}

Source: Authors Computation from Eviews. FEM

In accordance with the data processing as specified in Table 7, it was founded that at the significance level of 1 percent, there were two independent variables having a significant effect toward the unemployment rate, including graduation from basic education and population growth. Meanwhile, if a 5 percent significance level was used, it revealed that the GRDP variable of the secondary sector, tertiary sector, the graduation of high education, and the number of morbid males had a significant effect on unemployment rate. Then, for F-statistic, 43.83352 with the probability value of 0.000000 was discovered, meaning that the entire independent variable collectively affected the dependent variable of the unemployment rate significantly.

The value of determination coefficient aiming to measure how far the capability of the model to describe the variant of dependent variable was in the amount of 0.917976 , meaning that 91.80 percent of variant of unemployment variable could be explained by variant of economy social variable including GRDP of primary sector, GRDP of secondary sector, GRDP of tertiary sector, graduation of basic education, graduation of high education, the number of morbid male, as well as the population growth, while its remaining 8.20 percent was revealed by variant of other variables excluded from the model. 
While the regression equation stemming from the result of data processing as referred to in Table 7 was:

UNEMit $=-0.173947 \log$ PRIMERYit $-0.280066 \operatorname{logSECONDARYit~}-0.231207 \log$ TERTIARYit -5.494687 $\operatorname{logBASICEDUit}-1.059588 \operatorname{logHIGHEREDUit}+0.204497$ MORBIDMit +0.152414 POPit $+\beta_{0 i}+$ eit

Regarding the direction of the relation, it was founded that seven free variables had correlation way in accordance with the theory and previous study like as described in the previous section, in which the GRDP variable of primary, secondary, tertiary sector, graduation of basic education, and graduation of high education had negative correlation way, meanwhile, the number of morbid males and population growth had positive correlation way. Then, the graduation of basic education have the highest coefficient with the value of -5.494687 , followed by graduation of high education with the coefficient value of -1.059588 , GRDP of the secondary sector with the coefficient value in the amount of -0.280066 , and GRDP of the tertiary sector with the coefficient value of -0.231207 .

Why did the graduation of basic education have a sufficiently high coefficient value (tends to increase and decrease the unemployment rate by 5.49 percent) and have a negative correlation way? There are various reasons for the background. First, besides was deemed as the background of higher education, in which there are more resident obtaining and graduating from their basic education, meaning that it would open more opportunity to continue and obtain higher education, resident obtaining and graduating from their basic education also certainly had the difference with other resident who never experienced or had not graduated from their basic education either the difference of calculating, reading, writing skill and others, in which it was the key to work and have a business, in case they would not continue their education.

Second, the economy sector particularly the primary sector. Although primary sector was deemed as it was not the main focus any more within economy matters specifically in Java Island having an effect on the decreasing of production capacity due to the fact that land area continuously diminished (this also made GRDP of primary sector to not affect unemployment rate significantly), however, its movement still could be seen, the demand was still high, and the production was proceeded continuously, in which in this production process certainly required the production factor of labor force within this sector generally consisted of the resident graduating from basic education due to the cheap wage and over skill requirements. Since basically there was still any demand particularly in the economic activities of the primary sector and as long as it had not been fully replaced with the production factor of the machine, labor force graduating from basic education would be required. Besides the primary sector, other economy sectors also could not be denied that the employment graduating from basic education was required. Either in the secondary sector or tertiary sector, there must be working part which could not be managed by an individual with high education, even there were several sub-sector revealing that its employment was dominated by those graduating from basic education, like in the processing industry, construction, and trade. For a clear explanation, it could be seen from the following data.

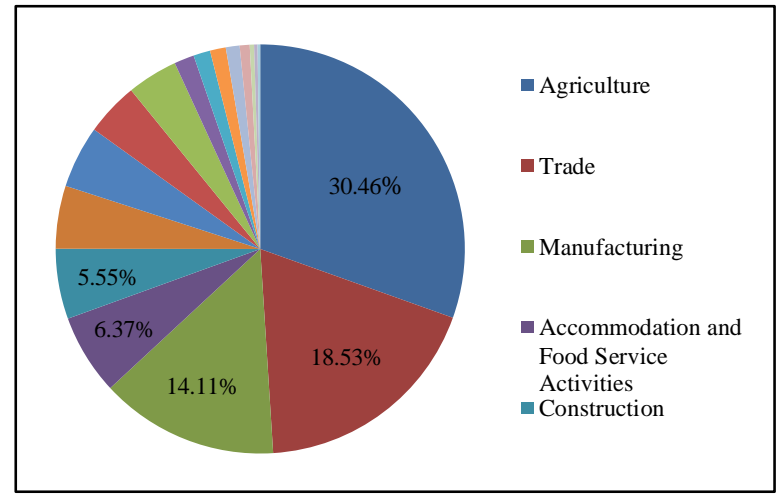

Source: BPS-Statistics Indonesia

Figure 2. Percentage of Working Resident in Indonesia Based on Economy Sector in 2018

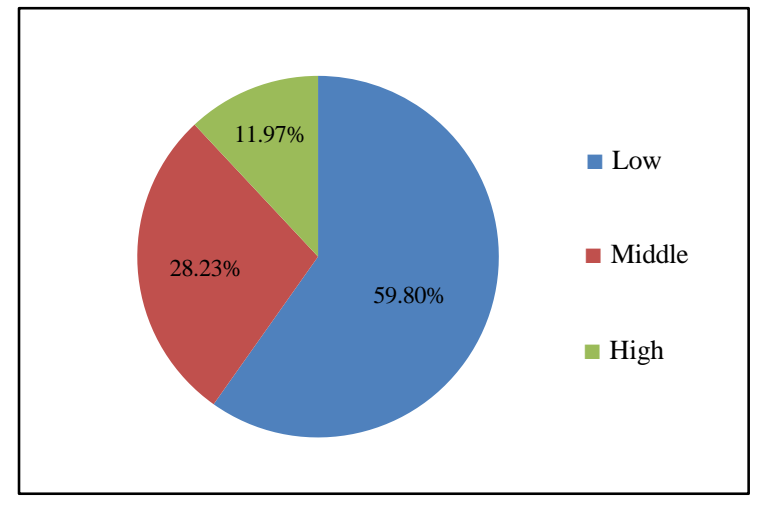

Source: BPS-Statistics Indonesia

Figure 3. Percentage of Working Resident in Indonesia Based on Highest Education in 2018

Figure 2 suggested that agriculture in the case of the primary sector in 2018 was still deemed as the economic sector revealing the high recruitment, even it was still the highest in Indonesia, followed by trade, processing industry, accommodation and food beverage, as well as the construction. In line with the aforementioned, it was founded that the graduation of basic education was the graduation with the highest percentage of working resident compared to the graduation of other education levels (see Figure 3), in fact meaning that more than a half of Indonesian employment composition was dominated by those graduating from basic education. Then in the sector of processing industry as part of the secondary sector, it was discovered that nearly half of total employment was the graduation of basic education as can be seen in the following picture. 


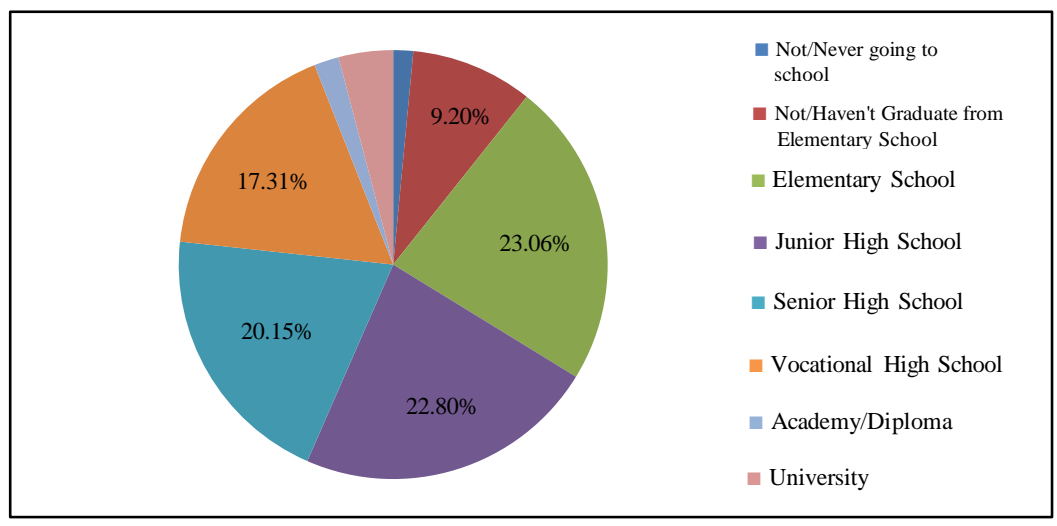

Source: BPS-Statistics Indonesia

Figure 4. Percentage of Employment in Processing Industry Based on the Education in 2018

It said that although the average school period of most resident in Java Island merely graduated from elementary school and junior high school, however, because it was supported by several economy factors which still recruited many employment graduating from basic education, it would be completely reasonable if the percentage of employment graduating from basic education was immense, and if the effect of this education number on unemployment rate was significant to negative correlation way and high coefficient value, although later it could be affected the weak competitiveness due to the fact that most employees had poorly weak quality.

\section{Conclusion and Recommendations}

In accordance with the findings, this research concludes that the graduation of basic education and population growth has a significant effect on the unemployment rate within the significance level of 1 percent. In the significance level of 5 percent, it discovers that GRDP of the secondary sector, GRDP of the tertiary sector, the graduation of high education, and the number of morbid males also have a significant effect. From the seven economy social variables, it is founded that the graduation of basic education was the variable mostly affecting the unemployment rate. 91.80 percent of the variant of unemployment rate variable in six provinces precisely in Java Island can be explained by the variable of economy social used in this research, while the remaining 8.20 percent is presented by a variant of other variables.

As the recommendation of the finding, there should be a special attention to the social variable in education field particularly the graduation of basic education to be encouraged to continue the higher-level education, although hitherto there are still many economy sectors recruiting the employment obtaining basic education, however in order to increase the competitiveness later, there should be attention for demographics sector i.e population growth. Due to the fact that Java Island is an island deemed as the highest population in Indonesia, the transmigration program can be one of the solutions. Besides it can balance the employment portion and the number of workforce, the transmigration is also effective to maximize the population distributed equally throughout Indonesia, so that the economic growth can be more proportional.

\section{References}

Adarkwa, S., Donkor, F., \& Kyei, E. (2017). The Impact of Economic Growth on Unemployment in Ghana: Which Economic Sector Matters Most?. The International Journal of Business and Management, 5, 1-3. Retrieved from http://internationaljournalcorner.com/index.php/theijbm

Antonisse, L., \& Garfield, R. (2018). The Relationship Between Work and Health: Findings from a Literature Review. KFF, Issue Brief. Retrieved from http://files.kff.org/attachment/Issue-Brief

Arsyad, L. (2015). Ekonomi Pembangunan (5th ed). Yogyakarta: UPP STIM YKPN.

Aryeetey, E., \& Baah-Boateng, W. (2007). Growth, Investment and Employment in Ghana. International Labour Organization, Working Paper No. 80. Retrieved from https://www.ilo.org

Basuki, A.T., \& Prawoto, N. (2016). Analisis Regresi dalam Penelitian Ekonomi dan Bisnis (1th ed). Jakarta: Rajawali Pers.

Ghozali, I., \& Ratmono, D. (2013). Analisis Multivariat dan Ekonometrika: Teori, Konsep, dan Aplikasi dengan EViews 8. Semarang: Badan Penerbit Universitas Diponegoro. 
Hasbullah. (2008). Dasar-Dasar Ilmu Pendidikan. Jakarta: Raja Grafindo Persada.

Liang, Y., Kahlenberg, J.M., \& Gudjonsson, J.E.. (2017). A Vestigal Pathway for Sex Differences in Immune Regulation. United State: National Center for Biotechnology Information. 14(7), 578-580. Retrieved from https://www.ncbi.nlm.nih.gov

Mankiw, N.G. (2007). Makroekonomi (6th ed). Jakarta: Erlangga.

Maqbool, M.S., et al. (2013). Determinants of Unemployment (Empirical Evidences from Pakistan). Pakistan Economic and Social Review, 51(2), 191-207. Retrieved from pu.edu.pk

Rahayu, S.K. (2010). Perpajakan Indonesia: Konsep dan Aspek Formal. Yogyakarta: Graha Ilmu.

Riddell, W.C., \& Song, X. (2011). The Impact of Education on Unemployment Incidence and Re-employment Success: Evidence from the U.S. Labour Market. Labour Economics, 18(4), 453-463. Retrieved from https://www.iza.org

Todaro, M.P. (2000). Economic Development. United States: Addison-Wesley.

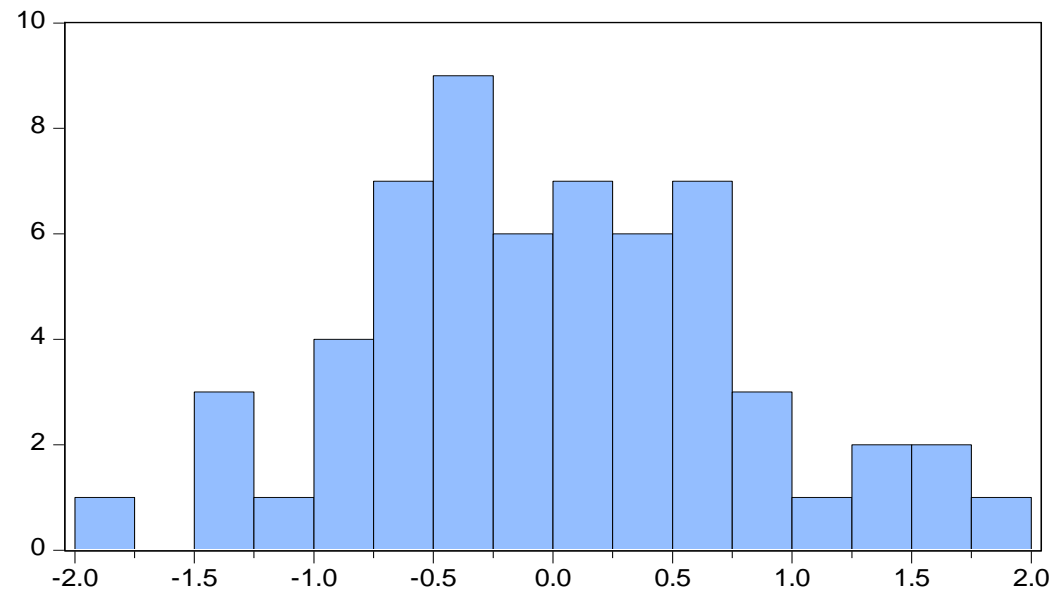

\begin{tabular}{|c|c|}
\hline \multicolumn{2}{|c|}{$\begin{array}{l}\text { Series: Standardized Residuals } \\
\text { Sample } 20092018 \\
\text { Observations } 60\end{array}$} \\
\hline Mean & $-2.50 e-16$ \\
\hline Median & -0.111566 \\
\hline Maximum & 1.972955 \\
\hline Minimum & -1.796627 \\
\hline Std. Dev. & 0.799795 \\
\hline Skewness & 0.267233 \\
\hline Kurtosis & 2.844786 \\
\hline Jarque-Bera & 0.774363 \\
\hline Probability & 0.678968 \\
\hline
\end{tabular}

Source: Authors Computation from Eviews

Figure. The Result of Residual Histogram and Jarque-Bera Test

Table. The Result of Correlation Matrix

\begin{tabular}{|c|c|c|c|c|c|c|c|c|c|}
\hline & X1 & $\mathbf{X} 2$ & $\mathbf{X 3}$ & X4 & X5 & X6 & $\mathbf{X} 7$ & X8 & X9 \\
\hline $\mathbf{X 1}$ & 1.000000 & 0.517219 & 0.067151 & 0.850252 & 0.794524 & 0.068578 & -0.412372 & -0.414643 & -0.281110 \\
\hline $\mathbf{X} 2$ & 0.517219 & 1.000000 & 0.518185 & 0.787752 & 0.836859 & 0.538641 & -0.589657 & -0.587799 & -0.074351 \\
\hline $\mathbf{X 3}$ & 0.067151 & 0.518185 & 1.000000 & 0.350864 & 0.461559 & 0.551668 & -0.324055 & -0.319897 & 0.126848 \\
\hline X4 & 0.850252 & 0.787752 & 0.350864 & 1.000000 & 0.971015 & 0.277115 & -0.639934 & -0.651019 & -0.166048 \\
\hline X5 & 0.794524 & 0.836859 & 0.461559 & 0.971015 & 1.000000 & 0.468617 & -0.627306 & -0.622139 & -0.153026 \\
\hline X6 & 0.068578 & 0.538641 & 0.551668 & 0.277115 & 0.468617 & 1.000000 & -0.235902 & -0.189796 & -0.016059 \\
\hline $\mathbf{X} 7$ & -0.412372 & -0.589657 & -0.324055 & -0.639934 & -0.627306 & -0.235902 & 1.000000 & 0.968445 & 0.132032 \\
\hline X8 & -0.414643 & -0.587799 & -0.319897 & -0.651019 & -0.622139 & -0.189796 & 0.968445 & 1.000000 & 0.077327 \\
\hline X9 & -0.281110 & -0.074351 & 0.126848 & -0.166048 & -0.153026 & -0.016059 & 0.132032 & 0.077327 & 1.000000 \\
\hline
\end{tabular}

Source: Authors Computation from Eviews

Note:

$\begin{array}{llllrl}\mathrm{X} 1 & =\text { PRIMERY } & \mathrm{X} 2 & =\text { SECONDARY } & \mathrm{X} 3=\text { TERTIARY } & \mathrm{X} 4=\text { BASICEDU } \\ \mathrm{X} 5 & =\text { MIDDLEEDU } & \mathrm{X} 6 & =\text { HIGHEREDU } & \mathrm{X} 7=\text { MORBIDM } & \mathrm{X} 8=\text { MORBIDF } \\ \mathrm{X} 9 & =\mathrm{POP} & & & \end{array}$

